\title{
Okul Yöneticilerinin Alo 147 Hakkındaki Görüşlerinin Bilgi Uçurma Açısından Değerlendirilmesi*
}

\section{The Evaluation of Views of School Administrators About Alo147 in Terms of the Whistleblowing}

\author{
Hayriye Sultan Tunç, ${ }^{\text {a,*** }}$ Asiye Toker Gökçe ${ }^{\mathrm{b}}$ \\ a Öğrt., Milli Eğitim Bakanlığg, Hakkaniye İlkokulu, 41000, Kocaeli/Türkiye. \\ ORCID: 0000-0003-0824-7908

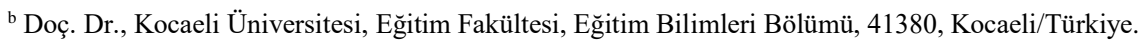 \\ ORCID: 0000-0003-1909-1822
}

\section{MAKALE BILGGISI}

\section{Makale Geçmişi:}

Başvuru tarihi: 28 Ekim 2017

Düzeltme tarihi: 11 Aralık 2017

Kabul tarihi: 18 Aralık 2017

Anahtar Kelimeler:

Bilgi Uçurma

Bilgi Uçurma Süreci

Okul Yöneticisi

Alo 147

\section{ARTICLE INFO}

\section{Article history:}

Received 28 October 2017

Received in revised form 11 December 2017

Accepted 18 December 2017

\section{Keywords:}

Whistleblowing

Whistleblowing Process

School Principals

Alo 147
ÖZ

Bu çalışmanın amacı okul yöneticilerinin ALO 147'ye yönelik görüşleri ve ALO 147'nin etkili kullanımına ilişkin önerilerini ortaya koymaktır. Nitel araştırma yöntemlerinden durum çalışması deseniyle yürütülen araştırmanın çalışma grubu, kota örnekleme yöntemiyle seçilmiş ve ALO 147 başvurularını cevaplamış 10 okul yöneticisi oluşturmaktadır. Araştırma verileri yarı yapılandırılmış görüşme yoluyla elde edilmiş olup, toplanan veriler içerik analizi yöntemiyle analiz edilmiştir. Analiz sonunda bulgular sekiz tema altında toplanmıştır. Bu bağlamda okul yöneticilerinin görüşlerine göre ALO 147'nin bilgi uçurma amacıyla kullanılmasının yanında kişisel husumet, politik oyunlar gibi farklı amaçlarla da kullanıldığı tespit edilmiştir. Okul yöneticilerine otokontrol sağlama gibi olumlu etkilerinin yanında baskı oluşturma, düşük motivasyon, duyarsızlık, fazla iş yükü, tükenmişlik ve itibar kaybı gibi olumsuz etkileri olduğu belirlenmiştir. Örgüte yönelik ise hesap verebilirlik ve şeffaflık sağlama, sorunlara karşı farkındalık oluşturma, sorunların erken çözümüne imkân tanıma gibi olumlu etkileri olduğu belirlenmiştir.

\section{A B S T R A C T}

The aim of this research is to put forward the views of the school principals related to ALO 147 which is a way of whistleblowing. In this research, case study design which is one of the qualitative research methods was used. 10 school principals who answered ALO 147 applications, participated in this research. These participants were selected by quata sampling method. At the end of the analysis, the findings were collected under eight themes. In this context, according to the opinions of the school principals ALO 147 is used for informational purposes as well as for other purposes such as personal animosity and political games. Besides its positive effects such as providing autocontrol to school administrators, it is determined that they have also negative effects such as pressure formation, low motivation, insensitivity, excessive workload, burnout and loss of motivation. Consequently, it is determined that it has positive effects such as providing accountability and transparency, creating awareness against problems, and enabling early resolution of problems.

\section{Giriş}

Günümüzde artan rekabet, teknolojik ilerlemeler ve küreselleşme sürekli değişimleri beraberinde getirmektedir. Örgütlerin yaşamlarını sürdürebilmesi bu değişimlere ayak uydurabilmelerine bağlıdır. Örgütlerde değişim örgüt içinden veya örgütün çevresinden aldığı dönütlerle yakından ilişkilidir. Örgütler sosyal ve açık sistemlerdir ve bir bütün olarak değerlendirilirler. Örgütün bir biriminde yaşanacak problemler diğer birimleri ve örgütün tamamını etkiler, iç ve diş çevreden gelen dönütlere cevap vermediği durumlarda ortaya çıkan entropi (güç yitimi) örgüt yaşamını tehlikeye atar.

\footnotetext{
* Bu çalışma, 11-14 Mayıs 2017 tarihlerinde Denizli'de düzenlenen 4.Uluslararası Avrasya Eğitim Araştırmaları Kongresi’nde bildiri olarak sunulmuştur.

** Sorumlu yazar/Corresponding author.

e-posta: hsultant@gmail.com
} 
Örgüt üyeleri örgüt içinde gerçekleştirilen eylemlerde etik davranışlara şahit olabilir. Örgüt üyeleri işyerindeki etik davranışları dile getirirken istekli ama şahit olduğu etik dışı davranışları dile getirmekte sessiz kalmayı tercih etmektedir (Doizer ve Miceli, 1985). Örgütlerde insan ilişkilerinin azalması ve örgüt içinde topluma ve örgütün hizmet sunduğu paydaşlara karşı olabilecek olumsuz durumların çoğalmasıyla birlikte örgüt içinde bu olumsuzlukları giderme veya sadece olumsuzluklar karşında sessiz kalmama, sesini duyurma çabasında olan çalışanların olduğu bilinmektedir (Baltac1, 2017a).

Brown (2008) yaptığı çalışmada örgüt içinde karşılaşılan ve şikâyete konu olan yanlış davranışları maddi kazanç için görevi suiistimal (rüşvet, yolsuzluk ve hırsızlık), çıkar çatışması, uygunsuz ve profesyonelliğe aykırı eylemler (resmi görevi kötüye kullanma gibi), kusurlu idare, kötü yönetim ve buna dayalı kaynak israfi, adaleti saptırma iş gören veya işyeri şikâyetleri şeklinde sınıflandırmıştır. Toker-Gökçe (2014a) okullarda öğretmenlerin tanık olduğu yanlış davranışları cinsel taciz, rüşvet alınması, okulun ödeneğinden para çalınması, okula ait pahalı/ucuz olabilecek bir eşyanın çalınması, kişisel çıkar için makamın kullanılması, kamunun sağlığını/güvenliğini tehlikeye sokacak bir uygulamaya/ duruma göz yumulması, kanunların veya yönetmeliklerin ciddi biçimde ihlal edilmesi, yönetmeliklerin uygulanmasında kişilere/gruplara ayrımcılık yapılması, bir müteahhit, danışman veya tedarikçiye hak etmediği halde yarar sağlanması, okulun parasını boşa harcayacak biçimde, kişilerden yarar veya hizmet alınması, komisyon alınması, kötü yönetilen bir program ile okulun kaynaklarının boşa harcanması, gereksiz veya eksik yarar veya hizmet alınarak okulun parasının boşa harcanması olarak sıralamıştır.

Örgütlerde olması muhtemel suiistimal, ihmal, sorumsuzluk gibi kamu yararını tehlikeye atan yanlış eylemleri ön görmek, bunlara karşı önlemler alabilmek örgütün varlığını devam ettirebilmesi için hayati öneme sahiptir. Örgütlerin yanlış eylemler sonucunda zarar görmemesi için; söz konusu eylemlere tanık olan bilgi sahibi kişiler tarafından, sorunları çözme güç ve yetkisine sahip kişilere sorunların bildirilmesi gereklidir. $\mathrm{Bu}$ sürecin tamamını bilgi uçurma kavramı ile tanımlamak mümkündür (Toker-Gökçe, 2014a).

Bilgi uçurma 1980 yılından sonra araştırmacıların ilgisini çeken bir konu olmuştur. Bilgi uçurma, bir örgütte gerçekleşen yasal olmayan, etik dişı, örgüte zarar verebilecek eylemleri, müdahale edebilecek kişi veya kurumlara bildirme işidir (Miceli ve Near, 1985). Bilgi uçurma Miceli vd., (1991) için, örgütsel haksızlığı önleyebilen ya da bir yanlışı telafi edebilen sosyal davranıştır. Rothschild ve Miethe (1999) bilgi uçurmayı örgütlerin etik olmayan davranışlarına karşı gözlemcinin toplumun iyiliği için yaptığı davranış; hayat kurtarmanın, yolsuzlukları ve sömürüyü durdurmanın bir yolu olarak açıklamaktadır. Bilgi uçurma, Aktan (2015) tarafından bir örgüt içerisinde yasadışı ve etik değerlere uygun olmayan davranış ve eylemlerin, örgüt içindeki veya dışındaki kişilere/kurumlara zarar vermemesi için bilgi sahibi kişiler (çalışanlar veya paydaşlar) tarafından sorunları çözme güç ve yetkisine sahip iç ve diş otoritelere bildirilmesi olarak tanımlanır. Aydın (2003) çalışanın işyerinde şahit olduğu yolsuzlukları, hukuka aykırılıkları ya da ihmal niteliği taşıyan eylemlere ilişkin bilgileri if̧şa etmesi, açığa çıkarması olarak ifade edilmiştir. Bilgi uçurma, özünde vicdani değer yargılarını kullanan kişilerce yolsuzluğa, kanunsuzluğa, ahlaksızlığa karşı gelme davranışıdır.

Bilgi uçurma eyleminin temelini etik ve hukuk kurallarına aykırı davranışları açığa çıkarma güdüsü oluşturur. Bilgi uçuran, kamu çıkarını tehdit eden bir durumu veya kişisel çıkarına ilişkin bir suiistimali veya ihmali aydınlatma amacı gütmektedir (Gundlach vd., 2008).

Bilgi uçurma anlık bir şikâyet etme durumu değil, örgüt üyesinin örgütte gözlemlediği örgüte zarar verebileceğini düşündüğü davranışı kendi düşünce sisteminden geçirerek harekete geçtiği bir süreçtir (Miceli vd., 1991). Miceli ve Near (1984) bilgi uçurmanın kişisel inanış ve örgütsel pozisyon ile ilişkisini ve bilgi uçurmaya ilişkin bir teori (1985) ortaya koymuşlardır. Bu çalışmalardan sonra bilgi uçurma, pek çok ülkede araştırma konusu olmuştur (Miceli ve Near, 1992; Chiu, 2003; Brown, 2008; Toker-Gökçe, 2013, 2014a, 2014b; Yeoh, 2014). Bilgi uçurma resmi veya resmi olmayan biçimde içe veya dişa, kimliğini açıklayarak veya kimliğini saklayarak gerçekleşebilir. Bilgi uçuranın gözlenen yanlışı örgütün belirlediği kurallara göre rapor etmesi resmi bilgi uçurma, güvendiği bir yakınına bildirmesi resmi olmayan bilgi uçurma olarak adlandırılır. Örgüt içinde, gözlemlenen yanlışı düzeltmeye yetkisi olan birilerine rapor edilmesi içe bilgi uçurma, yetkisi ve gücü olduğuna inanılan örgüt dışında birilerine bildirilmesi dışa bilgi uçurma olarak tanımlanır. Eğer bilgiyi uçuran bu sırada gerçek adını kullanıyor veya kimliğini açıklayıcı bilgi ekliyorsa kimliğ $i$ belirli bilgi uçurma, takma ad kullanıor veya kimliğini gizliyorsa anonim bilgi uçurma olarak tanımlanır (Lewis ve Vandekerckhove, 2015; Miceli ve Near, 1985; TokerGökçe, 2015).

Bilgi uçurmanın örgütsel etkileri düşünüldüğünde ikilem ortaya çıkmaktadır. Bilgi uçurma örgüt etkinliğinin artırılmasına yardımcı olacak değerli bilgiler sağlayabilir, yasal olmayan davranışların azalmasını sağlayabilir. Aynı zamanda örgütün otorite yapısını özellikle yöneticinin karar verme yetkisini etkileyebilir. Yöneticinin otoritesinde düşüşe; örgütte örgütsel sadakat, bağlılık ve performansın azalmasına neden olabileceğine dair çalışmalar bulunmaktadır (Miceli ve Near, 1985). Bilgi uçurma örgütsel düzeyde olumlu sonuçları beraberinde getirebilir. Bilgi uçuranlar davranışıyla örgütlerini itibar kaybı, örgüt kaynaklarının amaç dışı kullanılması gibi tehlikelerden korurken, örgütlerde etik olmayan davranışlara karşı toplumu korurlar (Özaslan ve Ünal 2016). Örgüte yönelik faydaları göz önüne alındığında bilgi uçurmanın teşvik edilmesi gereği doğar. Barnett, Cochran ve Taylor (1993) örgüt içerisinde çalışanların etik sorunları bildirebilecekleri örgüt içi politika ve iletişim kanallarının bulunmasının önemini vurgular. ABD, Birleşik Krallık, Romanya gibi bazı ülkelerde bilgi uçurmayı teşvik edici iletişim kanallarının oluşturulması ve bilgi uçuranların yasal olarak korunmasına yönelik uygulamalar bulunmaktadır (Lewis ve Vandekerckhove, 2015; Miceli ve Near, 1992; Yeoh, 2014). Türkiye'de de Başbakanlık İletişim Merkezi (BİMER), Cumhurbaşkanlığı İletişim Merkezi (CIMER), Milli Eğitim Bakanlığı İletişim Merkezi (MEBİM) gibi bilgi uçurmanın resmi kanallarla gerçekleştirilmesine yönelik uygulamalar olarak düşünülebilir. MEBİM bilinen adıyla ALO 147 Milli Eğitim Bakanlığı'nın yetki ve sorumluluk alanındaki eğitim kurumları ile ilgili bilgi edinme, talep bildirme, şikâyet veya 
ihbarda bulunma amacıyla faaliyete geçirilen; ayrıca bu hatta başvuranların etkin şekilde ve en kısa sürede çözümünü vaat eden bir iletişim kanalıdır.

\section{ALO 147}

Bilgi uçuma Türkiye'de hem yöneticiler, hem de iş görenler tarafından bilinen bir kavram değildir. Her örgütte yasa dış1, etik dışı uygulamalar ile karşılaşılabilir. Bu durumun en aza indirilebilmesi için iki yönlü iletişim kanallarının açık olması şarttır (Toker-Gökçe, 2014a). Milli Eğitim Bakanlığı bu iletişimi sağlayabilmek, eğitim sisteminin aksayan yerlerini görebilmek, sistemden etkilenen bireylerin sorunlarını çözüme kavuşturmak ve bilgi almak istedikleri konular hakkında MEB'e doğrudan ulaşılmasını sağalmak amacıyla 'ALO 147'olarak bilinen Milli Eğitim Bakanlığı İletişim Merkezi'ni (MEBİM) kurmuştur. ALO 147'nin hizmet tanımı ise Milli Eğitim Bakanlığı görev alanıyla ilgili vatandaşlardan gelen her türlü bilgi edinme, talep, görüşöneri, ihbar ve şikâyet başvurularının tek bir telefon numarası üzerinden hızlı ve etkin bir şekilde cevaplanması şeklinde tanımlanmıştır (KAYSİS, 2017). ALO 147 başvuruları Şekil-1' de belirtilen beş ana kategoriye sınıflandırılmakta, daha sonra başvurunun içeriğine göre (Öğretmenden memnuniyet, okul yöneticisinden memnuniyetsizlik, fiziki ve alt yap1 ihtiyaçları gibi) alt kategorilere göre işleme alınmaktadır ${ }^{1}$.

Şekil 1. ALO 147 Başvuru Sınıflandırması

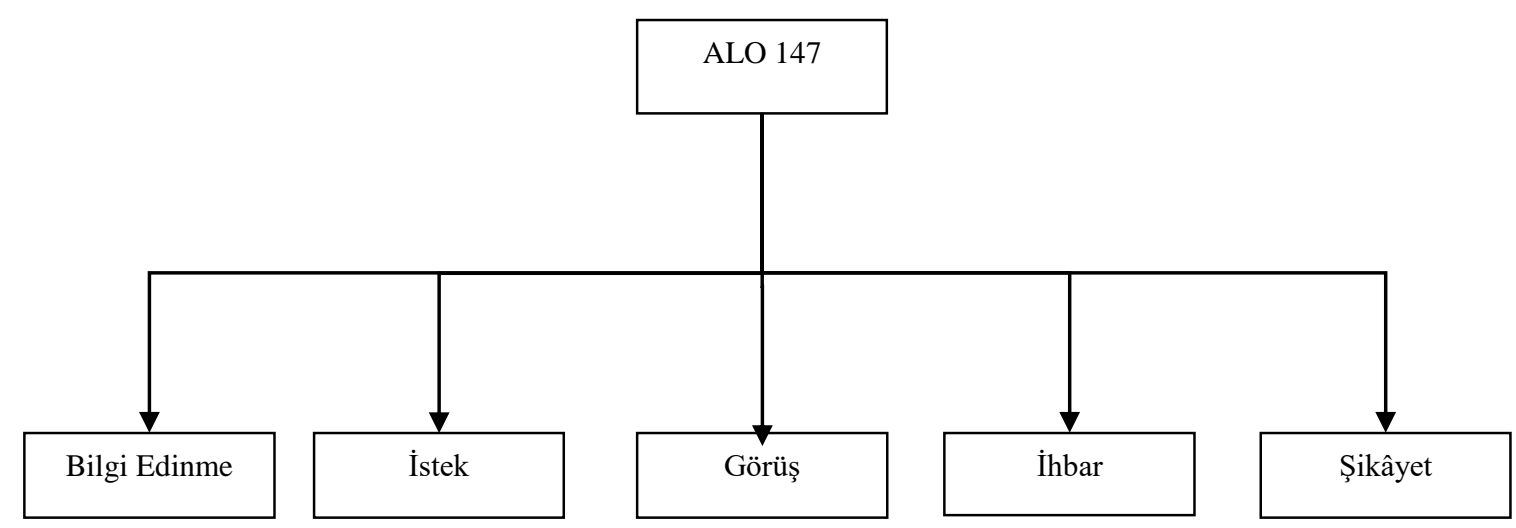

Milli Eğitim Bakanlığı'nın görev ve sorumluluklarıyla ilgili her türlü talep, şikâyet, görüş-öneri, ihbar ve bilgi edinme sorularını etkin ve hızlı bir biçimde çözüme kavuşturmak amacıyla kurulmuş ALO 147'ye yapılan ihbar ve şikâyet içeren başvurular resmi bilgi uçurma yollarından biri olarak düşülebilir. Ayrıca ALO 147 bilgi uçurma sırasında kimlik bilgilerini saklı tutarak anonim bilgi uçurma imkânı sunar. ALO 147 hattında başvuranların bilgi gizliliği, 6698 Sayılı Kişisel Verilerin Korunması Kanunu (Resmi Gazete, 2016) ile koruma altındadır.

Milli Eğitim Bakanlığı Basın ve Halkla İlişkiler Müşavirliği'nin yayınladığı 2012/02 sayılı genelge ile 2012 y1lında hizmete giren ALO 147'nin iletişim merkezi depremzedelere iș imkânı sunabilmek amacıyla Van ili Erciş ilçesinde kurulmuştur. İletişim merkezinde MEB mevzuat bilgisi konusunda eğitim görmüş uzmanlar vatandaşlardan telefon araması ile gelen ALO 147 başvurularını yanıtlamaktadır. Bakanlık tarafından işlem yapılması gereken ve hemen çözüm üretilemeyen konular, çözümü sağlayacak bağlı kurum kuruluşlara ivedilikle iletilmektedir (MEB, 2012).

MEB her il ve ilçede ALO 147 İletişim merkezinden gelecek konuları çözüme kavuşturmak amacıyla destek büroları oluşturmuştur. İletişim merkezinden destek bürolarına iletilen konular gerekli araştırmalar yapılarak 72 saat içinde çözülür, çözüme ilişkin yapılan çalışmalar hakkında iletişim merkezine dönüt verilir (MEB, 2012). Destek büroları gelen başvuruları çözüme ulaştırmada farklı stratejiler izleyebilmektedir. Destek bürosu ALO 147 başvurusuna konu olan kurumun yönetimiyle iletişime geçilerek bilgi isteyebilir, problemin çözüme kavuşturulması için kurum yönetimini yetkilendirebilir, başvuru doğrudan kurum yönetimi ile ilgiliyse başvuruyu gerekçe tutarak inceleme ya da soruşturma açılması talebinde bulunabilir. İnceleme ya da soruşturmalar farklı okullarda görev yapan ve makam onayı ile görevlendirilen okul yöneticileri (muhakkik) ya da maarif müfettişleri tarafından yürütülür. Bu süreç sonucunda devlet memurluğuna aykırı eylemlerde bulunduğu ya da bu eylemlere göz yumduğu belirlenen kişiler 657 Sayılı Devlet Memurları Kanunu'nda (Resmi Gazete, 1965) yer alan yaptırımlarla cezalandırılır. Başvuruların 72 saat içinde çözülmesi ve başvuru sahibine bilgi verilmesi esastır. Fakat bu sürede çözümlenemeyecek ya da inceleme-soruşturma gerektiren başvurular hakkında başvuru sahibine süreç ve sonuç hakkında bilgi verilmesi gerekmektedir. ALO 147 başvurularının çözümlenme süreci Şekil 2'deki gibi görselleştirilebilir.

\footnotetext{
${ }^{1}$ ALO 147 başvuru sınıflandırması ile ilgili bilgiler MEB tarafından yayınlanmadığı için şahsi ALO 147 araması ile edinilmiştir.
} 
Şekil 2. ALO 147 Başvurularının Çözüm Süreci

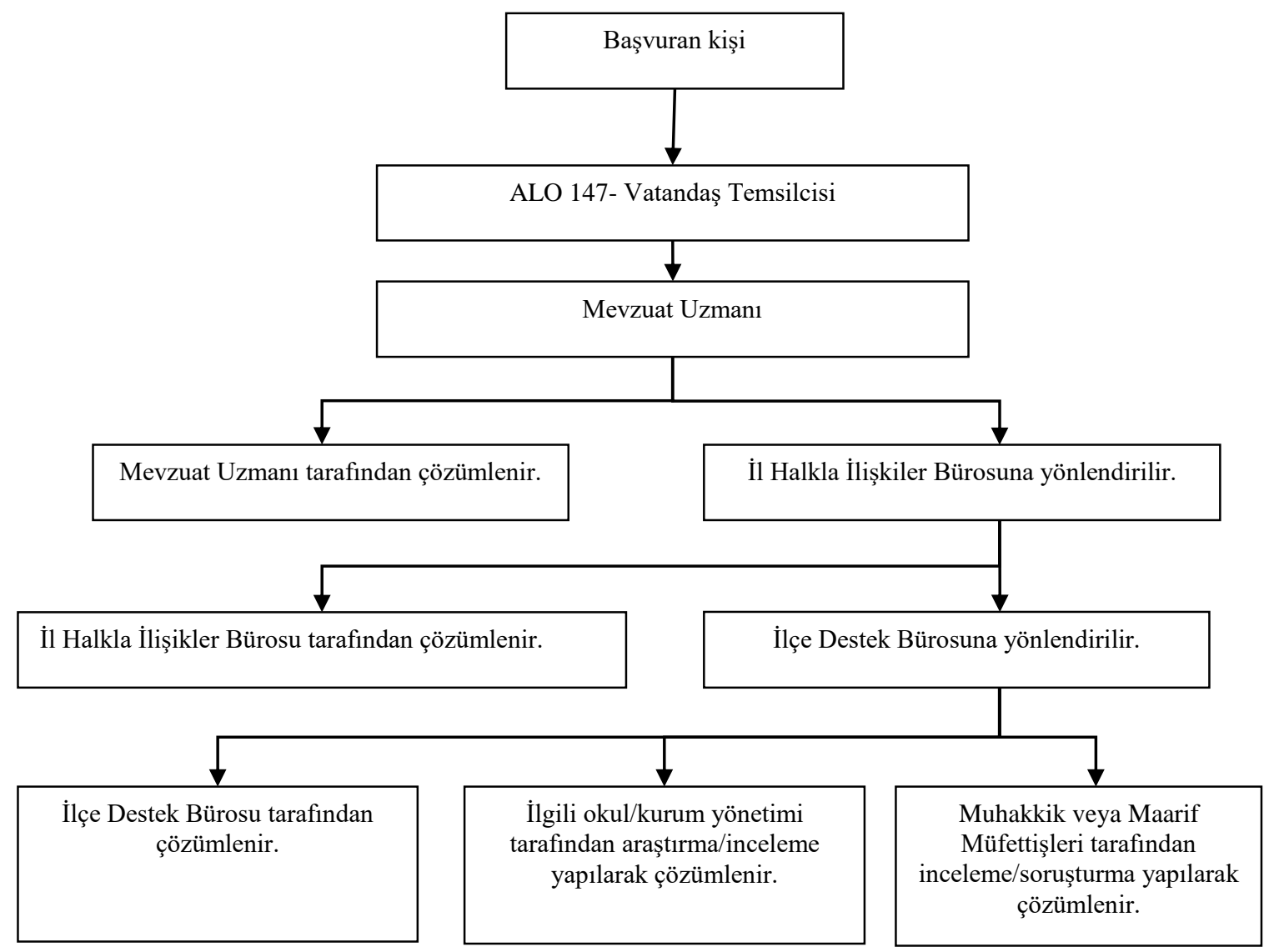

Not: ALO 147 Başvurularının çözüm süreci ile ilgili bilgiler Milli Eğitim Bakanlığı tarafından açıklanmadığı için şahsi arama yoluyla edinilmiştir.

Şekil 2 incelendiğinde okul yöneticileri, okul ve kurumları ilgilendiren ALO 147 başvurularının çözüme ulaştırılması sürecine farklı rollerle dâhil olmaktadır. Bu roller şu şekilde sıralanabilir:

(i) Başvuru okul içinde gerçekleştiği iddia edilen bir durumu konu aldığında birinci disiplin amiri olarak araştırmac1-incelemeci rolü.

(ii) Başvuru okul yönetiminin gerçekleştirdiği iddia edilen şikâyet ve ihbarları konu aldığında ihbar edilen rolü.

(iii) Başvuru başka okul veya kurumda gerçekleştiği iddia edilen şikâyet ve ihbarları konu aldığında muhakkik rolü.

Okul yöneticileri bu rolleri üstlendiğinde bazen çözüme ulaştıran yetkili kişi, bazen de suçlamalara maruz kalan kişi olarak görünmektedir. Çözüm sürecinde okul yöneticisinin çözüm sürecine yaklaşımı ve çözüme yönelik gösterdiği davranışlar önemli bir yer tutmaktadır. Bilgi uçurma pek çok ülkede desteklenen bir durum olsa da Türkiye'de olumsuz bir eylem olarak görülmektedir. Örneğin bir okul yöneticisinin öğrenci velisi tarafından darp edildiği iddiası ile okul yöneticileri tarafından gerçekleştirilen bir protestoda ve "Alo 147, Bimer, Cimer, Şimdi de Dayak" dövizlerinin açıldığı ve yapılan basın açıklamasında şu cümlelere yer verildiği görülmektedir (Adatavır, 2017):

"Alo 147' gibi öğretmeni toplumun önünde itibarsızlaştıran uygulamalar derhal kaldirllmalıdir. Bu ihbar hatlarında, birçok eğitim çalışanı iftiraya maruz kalmakta, ögretmenlik onurlarına halel gelmekte ve çalışma azimleri kırılmaktadır. Milli Ĕ̈itim Bakanlı̆̆l, personelinin savunucusu olmall, ögretmenleri sahipsiz ve savunmasız bırakmaktan vazgeçmelidir. Burada yaşanan bu olayda, asıl kaybedenin biz ögretmenler olmadı̆̆ını, geleceğimizi kaybediyor olduğumuzu ifade etmek istiyoruz."

Eğitim örgütlerinde bilgi uçurma sürecinden en çok etkilenenlerin, örgütün amacına yönelik yasal ve etik değerler çerçevesinde yönetilmesinden sorumlu olan okul yöneticileri olduğunu söylemek mümkündür. Bilgi uçurma, genellikle örgüt için bir tehdit olarak algılansa da yöneticiler tarafindan desteklendiğinde, örgütün etkililiğini ve sürdürülebilirliğini artıracak önemli bir araçtır (Gökçe, 2013). Akademik çevrede bilgi uçurmanın toplumsal yararları üzerinde anlaşmaya varılmış olsa da, yöneticilerin bu kaynağı nasıl şekillendirdiği konusunda sınırlı araştırma bulunmaktadır (Gökaslan ve Ünal, 2016; Lewis ve Vandekerckhove, 2015; Vandekerckhove, Brown ve Tsahuridu, 2014; Tsahuridu, 2011).

Okul yöneticilerinin bilgi uçurma konusundaki görüşlerinin ne olduğu hakkındaki belirsizliğin giderilmesi hem yönetim süreçlerinin işleyişi hem de hesap verebilirlik açısından önem arz etmektedir. Bu çalışmanın okul yöneticilerinin bilgi uçurma yollarından biri olan ALO 147'ye yönelik görüşlerini ortaya koyarak bilgi uçurulduktan sonra sürecin nasıl şekillendirildiği konusundaki belirsizliği gidererek literatüre katk1 sağlayacağı düşünülmektedir. Çalışmanın amacı "Okul yöneticilerinin bilgi uçurma yollarından biri olan ALO 147'ye yönelik görüşleri ve ALO 147'nin etkili 
kullanımına ilişkin önerilerini” ortaya koymaktır. Bu bağlamda aşağıdaki alt sorulara cevap aranmıştır:

(i) Okul yöneticilerinin ALO 147 öğretmen, öğrenci veya velilerin yaptığı başvuruların nedenleri ile ilgili görüşleri nelerdir?

(ii) Okul yöneticilerinin ALO 147 süreci hakkında görüşleri nelerdir?

(iii) Okul yöneticilerinin ALO 147'nin sonuçları hakkında görüşleri nelerdir?

(iv) Okul yöneticilerinin ALO 147'nin etkili kullanımına yönelik önerileri nelerdir?

\section{Yöntem}

\subsection{Araștırma Deseni}

Nitel araştırmalar algıların ve olayların doğal ortamda gerçekçi ve bütüncül şekilde ortaya konmasını ve bunlar hakkında derinlemesine bilgi edinmeyi sağlar (Yıldırım ve Şimşek, 2008). Bu bilgiden yola çıkarak derinlemesine bilgi edinebilmek için bu çalışmada nitel araştırma desenlerinden durum çalışması kullanılması uygun görülmüştür. Çalışma ALO 147 uygulaması hakkında okul yöneticilerinin görüşlerine dayalı durum çalışması deseninde tasarlanmış nitel bir araştırmadır. Baxter ve Jack'e (2008) göre durum çalışmasını bir durumun anlaşılmasına imkân veren çeşitli bakış açılarının keşfedilmesini kolaylaştıran bir desendir. Durum çalışmasını bir olayı meydana getiren ayrıntıları tanımlamak, olaya ilişkin açıklamalar geliştirmek ve olayları değerlendirmeyi amaçlar (Gall, Borg ve Gall, 1996). Bu nedenle çalışmada okul yöneticilerinin ALO 147 uygulamasından nasıl etkilendiklerini ve uygulama hakkında görüşlerini açığa çıkarmayı sağlamak için durum çalışması deseni tercih edilmiştir.

\section{2. Çalışma Grubu}

Araştırmanın çalışma grubunda Kocaeli ili İzmit ilçesinde 2016-2017 eğitim öğretim yılında ilkokul, ortaokul ve lise düzeyinde devlet okullarında görev yapan toplam $10 \mathrm{okul}$ müdürü ve müdür yardımcısı yer almaktadır. Araştırmanın çalışma grubu belirlenirken kota örnekleme yöntemi kullanılmıştır. Örneklem seçiminde ALO 147 başvurusu çözümünde yer alan ilkokul, ortaokul ve lise düzeyindeki okul yöneticilerinin eşit sayıda yer alması kota olarak belirlenmiştir. Her okul türünde gelebilecek başvuru türleri farklılık göstereceği için bütün durumları göz önünde bulundurabilmek amacıyla ilkokul, ortaokul ve lise türünden katılımcılara yer verilmiş ve katılımcıların ALO 147 başvurusunun çözümünde yer almış olmalarına dikkat edilmiştir. Araştırmaya katılımda gönüllülük esası önemle vurgulanmıştır. Belirlenen katılımcılara yönelik bilgiler Tablo 1'verilmiştir. Katılımcı bilgilerinin gizliliğini sağlamak amacıyla gerçek isimleri yerine takma isimlerle kodlanmıştır.

Tablo 1'de görüldüğü üzere katılımcıların 6'sı okul müdürü, 4'ü ise müdür yardımcısı olarak görev yapmaktadır. Okul türlerine göre 4 katılımcı lise, 3 katılımcı ilkokulda ve 3 katılımcı da ortaokulda yönetici olarak görev yapmaktadır. Cinsiyete göre bakıldığında katılımcıların 4'ü kadın ve 6'sı erkektir.
Tablo 1. Çalışma grubunu oluşturan katılımcı özellikleri

\begin{tabular}{llll}
\hline $\begin{array}{l}\text { Sira } \\
\text { No }\end{array}$ & Adı & Okul türü & Görevi \\
\hline 1 & Ahmet & İlkokul & Okul müdürü \\
2 & Mustafa & İlkokul & Okul müdürü \\
3 & Murat & İlkokul & Müdür Yardımcısı \\
4 & Kemal & Ortaokul & Okul müdürü \\
5 & Ayşe & Ortaokul & Müdür Yardımcısı \\
6 & Emine & Ortaokul & Müdür Yardımcısı \\
7 & Zeynep & Lise & Okul müdürü \\
8 & Mehmet & Lise & Okul müdürü \\
9 & Ali & Lise & Okul müdürü \\
10 & Fatma & Lise & Müdür Yardımcısı \\
\hline
\end{tabular}

\subsection{Veri Toplama Arac1}

Görüşmelerde yarı yapılandırılmış görüşme tekniği kullanılmıştır. Yarı yapılandırılmış görüşme tekniği önceden hazırlanmış soruların yanında görüşme sürecinde ihtiyaç duyulması halinde görüşülen kişiye yeni sorular sorulmasına imkân sağlar (Yüksel, Mil ve Bilim, 2007). Yarı yapılandırılmış görüşmede kullanılan görüşme formu yapılandırılmış görüşme formuna göre daha esnek, yapılandırılmamış görüşme formuna göre belirli bir çerçeve sunabilmesi nedeniyle veri toplama araci olarak yarı yapılandırılmış görüşmeye uygun olarak belirlenen çerçeve sorulardan oluşan yarı yapılandırılmış görüşme formu kullanılmıştır. Yarı yapılandırılmış görüşme formunda katılımcıların ALO 147'ye başvuru nedenleri, ALO 147 süreci, sonuçları ve etkili kullanımına yönelik görüşlerini ortaya koyacak sorulara yer verilmiştir.

\subsection{Verilerin Toplanmasi}

Araştırma verileri görüşmecilerin kendilerini rahat hissedecekleri önceden belirlenmiş yerde bireysel olarak ve randevu verdikleri tarihlerde gerçekleştirilmiştir. Her görüşmeciye sorulan sorular aynı anlamlara gelecek şekilde sorulmuştur. Okul yöneticileri ile yapılan görüşmeler not alarak ve görüşmecilerin izniyle ses kaydı yapılarak kaydedilmiştir. Yapılan görüşmeler 30-50 dakika sürmüştür.

\subsection{Verilerin Analizi}

Veri toplama aracı ile elde edilen verilerin analizinde içerik analizi tekniği kullanılmıştır. Yıldırım ve Şimşek’e (2008) göre içerik analizi verilerde saklı gerçeklerin ortaya çıkmasını sağlamak amacıyla, birbirine benzeyen verileri belirli kavramlar ve temalar çevresinde bir araya getirip, düzenleyerek yorumlamaktır. İçerik analizi sırasıyla verilerin kodlanması, temaların bulunması, kodların ve temaların düzenlenmesi, bulguların tanımlanması ve yorumlanması olarak dört aşamadan oluşur. Çalışmada içerik analizi uygulama aşamalarına uygun şekilde her alt probleme ait veriler kodlanmış ve temalar oluşturulmuştur.

\section{Bulgular ve Yorum}

Araştırmada elde edilen bulgular uygun şekilde aşağıda sunulmuştur. Okul yöneticilerin görüşlerinden elde edilen bulgular ALO 147'ye Başvuru Nedenlerine Yönelik Bulgular, ALO 147 Sürecine Yönelik Bulgular, ALO 147 Sonuçlarına Yönelik Bulgular, ALO 147'nin Etkili 
Kullanımına Yönelik Öneriler olmak üzere dört başlık altında toplanmıştır.

\subsection{ALO 147'ye Başvuru Nedenlerine Yönelik Bulgular}

Okul yöneticilerinin algılarına göre ALO 147'ye başvuru nedenlerine ilişkin görüşleri iletişim sorunları, kalıp yargılar/önyargılar, politik oyunlar ve yönetsel etkisizlik olmak üzere dört tema altında toplanmıştır. ALO 147'ye başvurularında iletişimsizlik, kolay ulaşabilirlik, çözümlerin tatmin etmemesi, çözüm süresinin kısalacağı düşüncesi, kesin çözüm beklentisi, art niyetli kullanım, baskı oluşturma, yönetici etkisizliği gibi nedenlerden kaynaklandığı ifade edilmiştir.

\subsubsection{ALO 147’ye Başvuru Nedenlerine Yönelik Bulgular}

İletişimsizlik: Çalışmaya katılan okul yöneticilerinin görüşlerine göre okulda yaşanan iletişim sorunları ALO 147'ye başvuru yapılmasına neden olmaktadır. Okul yöneticileri iletişim sorunlarının yüz yüze iletişimden kaçınma, düşüncelerini açıça ifade edememe ve çekingenlikten kaynaklandığını ifade etmektedir:

Kemal: Yönetime açıç̧a söyleyemedikleri şey, basit bir problem dahi olsa ALO 147'ye başvuru yapıyorlar. Örneğin, ögrencileri okula ilk kayıt ederken bă̆ış yapmalarını istiyoruz. Bu bă̆ıştan elde edilen gelirler, yine ögrenciler için temizlik, güvenlik gibi faaliyetlerde kullanllyor. Bunu ALO 147 'ye şikâyet etmektense bizimle konuşsalar onlara gerekli açıklamayı yapabiliriz.

Ali: Veli ve ögretmenler bizimle konuşmaya çekiniyorlar. Telefonla arayarak rahatsız oldukları problemi anlatmak onlar için daha kolay oluyor.

Zeynep: Veli ile ögretmen ve okul idarecilerinin sağlıkl iletişim kuramadı $\breve{g}$ ve yanlış anlamalar olması nedeniyle velilerin/öğrencilerin Alo 147 ye başvurduğu öncelikli fikrimdir.

Kolay ulaşılabilirlik: Okul yöneticilerine göre ALO 147'nin kolay şekilde ulaşılır olması, okul yönetimi ile yaşanan iletişim soruna çözüm olmaktadır. Konuya ilişkin bazı yönetici görüşleri şu şekildedir:

Ahmet: ...insanlar kolay şekilde, oturduklart yerden ALO 147 ye kolay ulaşım sağlayabiliyor. Bir telefon aracılığılyla derdini kolayca anlatıyor, sonrasında sadece çözümü beklemek kalıyor.

Murat: Akşamın bir saatinde, çayını içerken sadece telefonda 147'yi tuşlayarak derdine çare olabilecek birilerine ulaşmak ALO 147'nin en önemli kullanım nedenidir.

Okul yöneticilerine göre okulda yaşanan sorunlara tanık olan veya bu sorunlar nedeniyle mağdur olan veli ve öğretmenlerin okul yöneticilerine bildirilmesi durumunda problemin çözülebileceği ifade edilmektedir. Okul yöneticileri, okul yöneticilerinden ya da ALO 147'ye başvurandan kaynaklanan iletişim eksikliğinin ALO 147 kullanımıyla giderildiği, yüz yüze iletişim gerektirmemesi ve kolay ulaşılması nedeniyle tercih edildiğini dile getirmişlerdir.

\subsubsection{Kalıp Yargllar-Önyargılar Teması}

Çözümlerin tatmin etmemesi: ALO 147'ye başvuru nedenlerinin diğer bir neden okul yöneticilerine daha önceden bildirilen sorunlara yönelik çözümlerin tatmin edici bulunmaması olarak belirtilmektedir.
Ahmet: ...Ayrica insanlar yöneticilerle sorunu konuştuklarında ve sonuç alamadıklarında daha üst makamlara sıkıntılarını anlattıklarını düşündükleri için kullandıklarını düşünüyorum. Aynı iş yerinde çalışan bir kişiyi yine aynı iş yerinde çalışan bir kişiye Müdüre şikâyet etmekle çözülemeyeceği gerçeği yatmaktadır. Ama oyuna dişarıdan birini dâhil etmek daha cazip gelir her zaman.

Okul yöneticilerine göre okullarda sorunun çözülememesinin kişileri ALO 147'ye başvurmaya yönelttiğini belirtmektedir. $\mathrm{Bu}$ şekilde kişilerin daha üst makamlarla görüşerek çözüme ulaşmayı amaçladığı düşünmektedirler. Okul yöneticisinin hakkaniyetli davranmayacağı bu nedenle de problemin kurum içinde çözülemeyeceğine dair düşünceye sahip olduklarını dile getirmektedirler.

Çözüm sürecinin klsalması ve kesin çözüm beklentisi: Okul yöneticileri ALO 147'ye başvurmanın okulda karşılaşılan sorunun daha kısa sürede ve kesin çözüme ulaşılacağına yönelik düşüncelerden kaynaklandığını belirtmektedir.

Ahmet: Aslarla uğraşıp sürecin uzamasındansa sorunu en üst merciden tepeden inme hallettirmek isteniyor. Sonuçta burada okul müdürüne söyleyeceğimi gider bakanlı̆̆a söylerim gibi bir düşünceye kapılıyorlar.

Mustafa: Okul Müdürlüğü ile iletişime geçerek

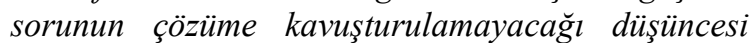
yerine Bakanlı̆̆a şikâyet edip şikâyete konu kişi hakkında inceleme-soruşturma açılması yönünde kesin çözüme kavuştuğunu düşünürler.

\subsubsection{Politik Oyunlar Teması}

Baskı oluşturma yöneticiyi itibarsızlaştırma: Okul yöneticilerine göre ALO 147'nın kullanım nedenlerinden biri de okul yönetimi üzerinde baskı oluşturma amacıdır.

Zeynep: En ufak olayda okul yönetimlerini şikâyet mercileri ile tehdit ettiklerini gördüm.

Ayşe: Ayrica başvuru yapanlar yöneticiyi ALO 147'ye şikâyet ederek okul müdürlerini itibarsızlaştırmayı hedefliyorlar.

Kişisel husumet: Okul yöneticileri kişisel anlaşmazlıkların iletişim hattına taşınmasını ALO 147'ye başvuru nedenlerinden biri olarak dile getirmektedir.

Ayşe: Problem ortaya çıktığında çözüm için şikâyette bulunmuyor bunu istese idareye gelir. Amaç öfkeyle problemi anlamadan karşıdaki kişiyi suçlamak için şikâyet ediyor. Başvuruların çoğu, kişisel garez ve husumetten, iftira ve zor durumda birakmayl amaçlar.

Emine: Her veli ile görüşüyorum, her velinin söylediği en ufak sorunu kayda alıp çalışmasını 
yapıyorum. Her okul böyle yapmayabilir. Öfke ve başka gaza gelme gibi nedenlerle 147'ye başvuruyorlar. Bana gelmeden oraya başvuranların çoğu kişisel husumetten dolayı başvuruluyor.

Art niyetli kullanım ve iftira: Okul yöneticilerine göre ALO 147 okul ile ilgili sorunlara çözümün yanında amaç dışı da kullanılmaktadır.

Mehmet: Şikâyetten çok bilgi edinme için kullanılmall. Bence ALO 147'nin kullanım amact okul müdürlerini şikâyet değil bilmediğimiz iş ya da işlemler ile ilgili bilgi almaktır. Ama insanlar problem yaşadiğ kişileri ihbar etmek için kullaniyorlar.

Fatma: Başvuranların çoğu, kişisel garez ve husumetten, iftira ve zor durumda birakmayl amaçlıyor.

\subsubsection{Yönetsel Etkisizlik Teması}

Yöneticilerin yetkisizliği-beceriksizliği: $\quad$ ALO 147 başvurularında okul yöneticilerinin yönetimde yetersiz kalması, okul yönetiminde yetki-sorumluluk dengesizliğinin ALO 147'ye başvuru yapılmasına neden olduğu belirtilmiştir.

Fatma: Sorun çözülsün diye bazen bizde veliyi yönlendiriyoruz. Okul Müdürlerinin ă̆ır iş yükü (bürokratik yükler, okulun fiziksel şartları gibi) sorunların çözümünü engelliyor. Benzer tavır ögretmenlerde de bulunuyor, okulda sorun çözülmüyor.

Murat: Öğretmen ya da veli gözlemlediği bir sorunu müdüre anlattığında tepki alacă̆ını düşünüyor. Tepki almadan soruna müdahale edilmesini sağlamak için ALO 147 'yi arlyorlar.

Kararlara katılım isteği: Okul yöneticilerine göre diğer paydaşların okul yönetiminde kararlara katılımın sağlanmadığı durumunda ALO 147'yi durumu bildirmektedirler.

Fatma: Okulda demokrasinin istenmesi de diğer bir durum. Öğrencilere, öğretmenlere değişiklik yapılan bir uygulamanin nedeni ile ilgili bilgilendirme yapılmıyor ya da danışılmıyor. Bu nedenle insanlar ALO 147'ye başvuru yaparak bu soruna çözüm bulmak istiyor.

\subsection{ALO 147 Sürecine Yönelik Görüşler}

Okul yöneticilerinin ALO 147 sürecine yönelik görüşlerine yönelik bulgular adaleti sağlamaya yönelik çalışmalar ve illegal istekleri reddetme olmak üzere iki başlık altında toplanmıştır. Okul yöneticileri başvuruyu işleme aldıklarında adaleti sağlamak için bilgi toplama, yüz yüze görüşme ve toplantılarla sorun hakkında bilgilendirme yapıldığını, başvuruların yasa ve yönetmeliklere ters düşmeyen durumlar hakkında veya başvuru gerçeği yansıtmayan durumları konu aldığında reddedildiğini belirtmişlerdir.

\subsubsection{Adaleti Sağlamaya Yönelik Çalışmalar Teması}

Bilgilendirme ve çözüme yönelik adımlar: Okul yöneticileri başvurular kendilerine ulaştığında şikâyet konusunun yeterli bilgi sahibi olmamasından kaynaklandığı durumlarda kişilere bilgilendirme yapıldığını belirtmektedirler. Eğer şikâyet konusu ile ilgili daha önce bilgi sahibi değillerse okul içinde gerekli araştırmaları yaparak çözüme yönelik uygulamalar gerçekleştirdiklerini dile getirmektedirler.

Fatma: Sorunu dile getiren ile görüşmeye çalışıyoruz. Mesela biz sürekli okulda para toplaması yüzünden şikâyet ediliyoruz. Para toplandı̆̆ında toplanan paraların neden toplandiğg ve hangi ihtiyaçları gidermek için kullanıldığ herkese bilgi veriyoruz. Veliler ile toplant yaparak gerekçelerimizi anlatıyoruz. Konuyla ilgili bilgi sahibi olmayan, okula hiç gelmeyen veli ALO 147'ye şikâyet ediyor.

Mehmet: ...Gelen şikâyetin doğru olup olmadı̆̆ını, ortada ĕ̆er haksızlı̆̆a neden olan ve doğru olmayan bir sorun varsa adaleti sağlamak için gerekli incelemeleri yaparak sonuçlandırmaya çalışlyorum. Sonuçta o okuldan ben sorumluyum ve her çocuğa eğitim hakkını sağlamak ve sistemin düzgün şekilde işlemesini sağlamak benim görevim.

Zeynep: Konunun gerçekliğini araştırmak, farkl şahitler bulmak, şikâyet edilen konunun geçmişteki delillerini de göz önünde bulundurarak şikâyet edilen durum ile doğrudan ilişkili birim veya kişilerle konuşmak ilk yapılacak eylemdir. Olayın gerçekliği yoksa telkinle söylemek, neden şikayet edildiğine dair empati kurmasını sağlamak şikayet eden kişinin ruh halini ve isteğini kavramaya çalışmak ikincil izlenecek yoldur. Ĕger şikâyet konusu kanun, yönetmelikler, pedagojik ve etik değerler dişında davranışlarl kapslyorsa kanun ve yönetmelikleri uygulamak için bir üst birimlere paylaşımda bulunmak son aşamadır.

\subsubsection{Başvuruyu Reddetme Teması}

Illegal istekleri red ve başvuruyu reddetme: ALO 147 başvurusunda geçen konu keyfi sınıf değiştirme, alım bölgesi dışından okula kayıt isteği gibi uygulanması mümkün olmayan ya da gerekçesi olmayan başvuruları geri çevirme, okul yöneticilerinin sürece yönelik görüşleri arasındadır.

Ahmet: ...kayıt bölgesi dışında bulunan öğrencilerin ısrarla kaydını bu okula almayı isteyen veliler şikâyetlerde bulunabiliyor. Bu gibi istekleri nedenleri ile birlikte açılayarak reddediyoruz.

Ayşe: ... Ancak şimdiye kadar yapılan başvurular çözülebilecek problemler değil, kural dışı istekler yapılmadığ olarak kullanmak isteyip, bu nedenle gerçekleştirmiyoruz.

\subsection{ALO 147 Sonuçlarına Yönelik Görüşler}

Okul yöneticilerinin ALO 147'nin sonuçlarına yönelik görüşleri yöneticiye yönelik ve örgüte yönelik görüşler olmak üzere iki tema altında toplanmıştır. 


\subsubsection{ALO 147'nin Yöneticiye Yönelik Sonuçları Temast}

ALO 147'nin bask1 altında hissetme, düşük motivasyon, stres, şikayetlere karşı duyarsızlık, daha fazla iş yükü, tükenmişlik, iftiraya maruz kalma, imaj-itibar kaybı gibi olumsuz etkilerinin yanında otokontrol sağlayarak daha dikkatli olmayı sağlama gibi olumlu sonuçları olduğu okul yöneticileri tarafindan belirtilmektedir.

Ahmet: Olumlu bir yönü olarak değerlendirmesem de yöneticilerin daha dikkatli ve kontrollü olmasını sağllyor.

Mustafa: Baskl altinda kalmama, moral bozucu, karar tekrar sorgulamaya şüphe duymama neden oluyor.

Kemal: Çok iş yükü getiriyor. Eğer şikâyet edilen ben ya da benim kurumumsa savunma gereği hissediyorum. Ĕger başka bir okul hakkinda yapılmisssa ve ben muhakkik olarak görevlendirilmişsem daha fazla iş çıklyor.

Zeynep: Şikâyet edilen ögretmen haksız yere şikâyet edildiğini düşünüyorsa, genelde böyle, ise ve ögrenciye adanmışlı̆̆ı azalıyor, tükenmişlik sendromuna giriyor.

\subsubsection{ALO 147 'nin Örgüte Yönelik Sonuçları Teması}

Okul yöneticilerine göre ALO 147'nin örgüte yönelik sonuçlarında; örgütü iyileştirme, örgütü koruma, şeffaflık, sorunları görme (farkındalık) ve firsat olarak algılama olmak üzere beş bulguya ulaşılmıştır.

Ahmet: Olumlu etkileri vardır, Şikâyetlerin daha fazlasın engellemek için. Ben bu başvurular neticesinde herhangi bir konuda yöneticilerin ya da ögretmenlerin suçu varsa, yönetmeliklere ya da ahlak dışı davranışları oluyorsa bunun sonunda ceza almast gerekmektedir. En azından gelen bu başvurularda bildirilen durumların gerçekten var olup olmadı̆̆ına bakılmalıdır.

Fatma: ALO 147'nin yönetime büyük katklsı oluyor. Şeffaf yönetimi sağllyor. Biz önce yönetime başvurulması durumunda sorunu çözebileceğimizi, çözümü olmaması durumunda 147'ye başvurulması yönünde telkin ediyoruz. Böyle hakkinın olduğunu bilmek kişiye güven veriyor.

Ali: Kurumda varlığından haberdar bile olmadığımız bazı problemleri öğrenmemize ve bunlara karşı önlem almamiza yardımcı olan bir uygulama olduğu söylenebilir.

\subsection{ALO 147'nin Etkili Kullanımına Yönelik Öneriler}

Okul yöneticilerinin ALO 147'nin etkili kullanımına yönelik önerileri incelendiğinde iletişim hattının kategorize edilmesi, il merkezli iletişim hatlarına dönüştürülmesi, iletişim hattı hakkında veli ve ögretmenlere bilgilendirme yapılması, muhakkik görevlendirmesinin yöneticiler dışındaki uzmanlara verilmesi gibi görüşler yer almaktadır.
Ayșe: Il Her ilin ya da her ilçenin kendi iletișim hattı olsa bence daha kullanışl olur. Ya da sikâyetlerin okullardan başlayarak ilçe milli eğitim müdürlüklerine, oradan il milli eğitim müdürlüklerine gitmesi șeklinde sirall bir yol izlenebilir. Böylece şikâyet süreci daha kolay yönetilebilir. Hatta Okula ait hat olmast düşünülebilir.

Fatma: ALO 147 başvurularinda devlet memurunun, iftira durumunda şikâyetçiye karşı devlet tarafindan korunma durumu olmalı. Yani olmayan bir suçla itham edildikten sonra biz ismini gizleyen şikâyetçiye karşı herhangi bir işlem yapamıyoruz. Bunun dışında Yerelde bir çalışma yapıldı̆̆ında okul müdürlerinin muhakkik olarak görevlendirilmesi yerine, inceleme soruşturma veya araştırmaları özel denetmenler tarafindan yapılması daha etkili olacaktır. Neticede bir okul müdürünün başka bir müdür tarafindan soruşturması herhangi bir sonuca ulaşmiyor.

Mehmet: Illçelerde doğrudan bu başvuruları alabilecek birimlerin kurulması daha etkili ve hızl çözüm sağlayabilir.

Ali: ALO 147'nin varlığ hissettiriyor. Bu nedenle bu hattın açık kalması gayet güzel. Fakat başvuruları sonuca kavuşturmada problemler yaşanlyor. Başvurulardan gelen şikâyetleri incelemesi için çoğunlukla muhakkik görevlendirmesi yapılyyor. Yani bir okul müdürü gidip başka bir okul müdürü hakkinda inceleme ya da soruşturma yaplyor. Bu bence yanllş bir uygulama bunun yerine farkll tarafsı kişiler gelip inceleme yapmalı ki, gerçekler ortaya çıkabilsin.

Murat: ALO 147'nin etkili olması için önce veli, ögretmen, ögrenci hatta yöneticilerin bilgilendirilmesi gerektiğine inaniyorum. Böylece başvuruların niteliği artacak ve angarya saylabilecek başvurular ortadan kalkacăğ için daha etkili kullanilacaktır.

Zeynep: Başvurular duygusal bir söylemle itibar sarsıcı ve iftira ise bunun karşıllı̆ııda şikâyet edenin bir bedel ödemesi ve yanlls ihbardan dolayı bir yaptırıma maruz kalması gereklidir. (En basiti Para cezasl vb. gibi) Şikâyet ederken de Bakanlığa veya kimsesiz çocuklara veya çevre güzelleştirme vakiflarına sembolik de olsa bir pul alarak yardımda bulunması gereklidir.

\section{Sonuç ve Değerlendirme}

ALO 147'ye başvuru nedenlerine yönelik okul yöneticilerinin görüşlerinden elde edilen iletişim sorunları ve yönetsel etkisizlik temalarında elde edilen bulgular çıkar çatışması, uygunsuz ve profesyonelliğe aykırı eylemler, kusurlu idare, kötü yönetim, adaleti saptırma gibi örgütlerde görülen etik veya yasal olmayan davranışlardandır. Örneğin 222 Sayılı İlköğretim ve Eğitim Kanunu'nda devlet okullarında eğitimin parasız olduğu ifade edilmektedir (Resmi Gazete, 1961). Okul yöneticilerin görüşlerine dayalı elde edilen bulgularda öğrencilerden bağış adı altında olsa da para istendiği, toplanan paraların okulun ihtiyaçları için kullanıldığı belirtilmiştir. Bu uygunsuz ve profesyonelliğe 
aykırı olmakla birlikte yasal değildir. Bu gibi durumlarda ALO 147'ye yapılan şikâyetler, başvuranın kişisel çıkarlarını hizmet etse de bilgi uçurma kapsamında değerlendirilmesi mümkündür.

İletişim sorunları iletişimin iki önemli unsuru alıcı ve verici arasında gerçekleşmektedir. Bulgularda rastlanan iletişim sorunları okul yöneticilerinin sorunları olan kişileri yeterince dinlememesinden kaynaklanıyor olabilir. İkinci muhtemel sebep ise ALO 147'ye başvuran kişilerin okul yönetimi ile sorunları paylaşmaktan çekinmesi veya okul yöneticisi ile kişisel husumet olabilir. Gerçek (2005) yöneticilerin bilgi uçuranlara karşı mobbing, zayıf sicil üretme, tehditle sessizliğe zorlama, yalnız bırakma, aşağılama, başarısızlığa yönlendirme gibi tipik misilleme ve öç alma yaklaşımlarını uyguladıklarını belirtmektedir. ALO 147'ye başvuranların sorunları okul yöneticisi ile paylaştığında okulda kendisinin ya da veli ise öğrencisinin mobbing, misilleme gibi olumsuz eylemlere maruz kalmaktan çekiniyor olabilir.

Okul yöneticilerinin ALO 147'ye başvuru nedenlerine yönelik görüşlerinden elde edilen iletişim" politik oyunlar" ve "kalıp yargılar" temalarında bulgular ALO 147'nin bilgi uçurma amacıyla değil, kişisel hesaplaşma aracı olarak kullanıldığını, tehdit olarak algılandığını göstermektedir. Sağyan ve Bedük (2011), erdeme sahip kişilerin etik sorunlar karşısında susmayarak gerçeği başka kişilere aktarmanın kişisel sorumluluk ve etik değerlerin gereği olduğunu ifade etmektedir. Bilgi uçurma kişisel hesaplaşma ya da ispiyonlama değil, tanık olunan sorunun üçüncü kişilere ve örgüte zarar vermesini engelleme amacıyla gerçekleştirilen bir davranıştır. Okul yöneticilerinin ALO 147'ye ilişkin bu görüşleri; bilgi uçurmanın okul yöneticileri ve başvuranlar tarafindan yeterince bilinmemesinden ve yönetimde bilgi uçurmadan etkili şekilde faydalanmamasından kaynaklanabilir.

ALO 147 sürecine yönelik okul yöneticilerinin görüşlerinden elde edilen "Çözüme Yönelik Adımlar" temasında, uçurulan bilginin kurallara uygun şekilde incelenmesi, bilginin doğru olması durumunda önleyici tedbirler aldığı ve durum ile ilgili bilgilendirme yaptığ görülmektedir. Miceli vd.'in (2009) açıkladığı “etik dışı eylem olabileceği düşünülen bilginin dile getirilmesinden sonra örgütün devamlılığını ve sürekliliğini sağlamak adına yöneticinin uygulaması gereken eylem planına uygundur. Böylece okul yöneticilerinin örgüt iklimini ve sağlığını korumak amacıyla çeşitli çalışmalar yaptığı söylenebilir. Fakat yapılan inceleme, araştırma veya soruşturma sonunda başvuruda geçen iddiaların asılsız olması moral-motivasyon düşüklüğü, tükenmişlik gibi olumsuz sonuçları beraberinde getirebilir.

Okul yöneticilerinin ALO 147 sürecine yönelik görüşlerinden elde edilen "iddiaları reddetme" temasındaki bulgularda gelen başvuruların etik dışı bir olayı açığa çıkarmadığını aksine, başvuruda yasa dışı isteklerin yer alması nedeniyle iddiaların reddedildiği belirtilmiştir. Örneğin ilköğretim çağındaki öğrencilerin okula kayıt ve başka okula nakil durumu Okul Öncesi Eğitim ve İlköğretim Kurumları Yönetmeliği’nde belirtildiği üzere ulusal adres veri tabanındaki veli adres bilgileri esas alınarak belirlenir (Resmi Gazete, 2014). Fakat bu konu hakkında yetersiz bilgiye sahip olan velilerin öğrencilerinin önceden belirlenmiş okul dışındaki okula kayıt yaptırmak istediğinde ve bu isteği okul yönetici tarafından gerçekleştirilmediğinde
ALO 147'yi arayarak okul yöneticisini şikâyet ettiği okul yöneticileri tarafindan dile getirilmiştir. Böyle bir durumda söz konusu şikâyetin herhangi bir yasadışı eylemi açığa çıkarma amacıyla değil bilgi eksikliğinden kaynaklandığı söylenebilir. $\mathrm{Bu}$ durumda bilgi uçurmanın ülkemizde yeterince bilinen bir kavram olmaması nedeniyle ALO 147 gibi iletişim kanallarının amaç dışı kullanımının söz konusudur.

Okul yöneticilerinin ALO 147 sonucuna yönelik görüşlerinden elde edilen bulgularda ALO 147'nin yöneticilerde baskı altında hissetme, motivasyon bozma, duyarsızlık, tükenmişlik, imaj kaybı, zorunluluk hissetme gibi etkilere neden olduğu belirlenmiştir. Baltacı ve Balcı (2017) ALO 147 şikâyetlerinin okullarda eğitim çalışanlarının çalışma isteğini ve iş verimini azaltan bir olgu olduğunu, özellikle veliler ve öğrenciler tarafından yoğun bir şekilde kullanılan şikâyet sistemi ile okullarda gerçekleşen her türlü olumsuz davranış veya veli ve öğrencinin hoşuna gitmeyen durumu bildirmek amacıyla kullanıldığını belirtir. Bu etkiler bilgi uçurmanın tehdit olarak algılanması, denetim mekanizması olarak görülmesi ve yasal yaptırım gücüne sahip olması, başvuranların kişisel çıkarı çatışmaları ve anlaşmazlıklar sonucu bilgi uçurması gibi nedenlerden kaynaklanıyor olabilir. Ayrıca okulların çözümü 72 saat veya daha az bir sürede çözüme ulaştırması gerekliliği de bulguların ortaya çıkmasına neden olabilir.

Yine ALO 147 sonucuna yönelik görüşlerinden elde edilen bulgularda ALO 147'nin yöneticilerde otokontrol sağlama, örgütü korumaya/iyileştirmeye yardımcı olduğu, şeffaflık ve hesap verebilirliği sağladığı ve sorunlara karşı farkındalık oluşturduğu belirtilmiştir. Miceli ve Near (1985) örgütün etkililiğini ve sürdürülebilirliğini sağlamada bilgi uçurmanın önemli yaraları olduğunu belirtir. Aktan (2006) örgütteki yasa/etik dişı eylemlerin sorunu çözme güç ve yetkisi olanlara bildirerek başka kişilere veya kurumlara zarar vermemesini sağlamak amacıyla bilgi uçurmanın gerçekleştirildiğini belirtir. Baltacı (2017b) Bilgi uçurma ile örgütün kendisini arındırdığını böylece yöneticilerin örgüt içinde olan biteni daha iyi anlama firsatı bulduğunu ifade eder. Okul yöneticileri ALO 147'nin kendilerine yönelik pek çok olumsuz etkisi olduğunu ifade etse de, örgütsel düzeyde getirileri olduğunu ifade etmektedir. $\mathrm{Bu}$ da okul yöneticilerinin ALO 147 başvurularından aldığı dönütleri yönetim sürecine dâhil ederek okulun etkililiğini sağlamak için kullandığının bir göstergesi olarak düşünülebilir.

Tüm bu bilgiler 1şığında ALO 147'nin Milli Eğitim Bakanlığı tarafından açılmış, bakanlığa bağlı kurumlarda görülen etik/yasa dışı eylemleri açığa çıkarmak için kullanılan bilgi uçurma kanalı olduğu bulgularla desteklenmiştir. Okul yöneticilerinin görüşleri ALO 147'nin bilgi uçurmadan daha çok art niyetli kullanıldığı yönündedir.

Araştırma sonucunda bilgi uçurma ve bilgi uçurma kanallarının etkili kullanımı doğru şekilde bilinmediği görülmüştür. Eğitim örgütlerinde bu eksiği gidermek amaciyla öğretmen ve yöneticilere bilgi uçurmanın örgütsel faydaları hakkında toplantı veya okul projeleri gibi farkındalık çalışmaları yapılması faydalı olacaktır. Ayrıca bilgi uçurma ve ispiyonculuk kavramları birbirinden ayrı eylemleri tanımlamaktadır. ALO 147 ispiyonculuk olarak değil örgütsel gelişimi ve kurum itibarı koruyacak bir iletişim hattı olarak kullanılmalıdır. Böylece yöneticilerin 
ALO 147 sonucunda yaşadığı baskı, motivasyon kaybı, tükenmişlik gibi etkilerin azalması mümkün olacaktır.

Devlet memurlarını isnat ve iftiradan koruma amaciyla 657 Sayılı Devlet Memurları Kanunu 25. Maddesinde "Devlet memurları hakkındaki ihbar ve şikâyetler, garaz veya mücerret hakaret için, uydurma bir suç isnadı suretiyle

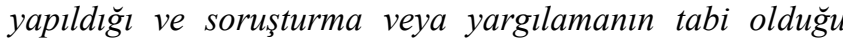
kanunî işlem sonucunda bu isnat sabit olmadiğl takdirde, merkezde bu memurun en büyük amiri, illerde valiler, isnatta bulunanlar hakkında kamu davası açılmasını Cumhuriyet Savcılığından isterler." ifadesine yer verilmektedir. Bilgi uçurma kanallarının art niyetli kullanımı durumunda okul yöneticisi ve personelinin kendini iftira ve asılsız şikâyetlerden yasal ve hukuki işlemlerle koruma güvencesi bulunmaktadır. Bu gibi durumlarda ilgili kanun maddesinde belirtilen yollarla kendilerini savunmaları durumunda yöneticilerin itibarlarını korumaları mümkün olacaktır.

ALO 147'nin etkili kullanımı sağlamak amacıyla başvuranların bilgilendirilmesi ve iletişim hattının kullanımına yönelik farkındalık oluşturulması önem arz etmektedir. İl-ilçe düzeyinde ALO 147 ve bilgi uçurma konusunda uzman kişilerce öğrenci ve veli boyutlarında bilgilendirme çalışmaları yapılabilir. Böylece hem başvuruların daha nitelikli olması sağlanabilir, hem de yöneticilere gereksiz iş yükü oluşmasının önüne geçilebilir. Okul yöneticilerinin ALO 147 başvuru sürecinde incelemesoruşturma işlemlerini yürütmenin iş yükünün artması ve inceleme-soruşmanın tarafsız yürütülememesi nedeniyle etkili olmadığını belirtmişlerdir. $\mathrm{Bu}$ olumsuz durumun önüne geçilebilmek amacıyla inceleme-soruşturmayı gerektiren başvurularda işlemin okul müdürleri yerine müfettişler tarafından gerçekleştirilmesi önerilebilir.

Bilgi uçurmayı anlamak ve etkili kullanımını sağlamak amaciyla veli, öğrenci, öğretmen, okul yöneticileri ve yerel yöneticiler düzeyinde çeşitli çalışmalarla farkındalık oluşturma çalışmaları gerçekleştirilebilir. Bilgi uçurmanın teşvik edilmesi ve doğru şekilde gerçekleştirilmesine yönelik örgütsel düzeyde politikalar oluşturulabilir. Böylece bilgi uçurma yollarından olan ALO 147'nin etkili ve verimli kullanılması sağlanabilir. ALO 147 hattının kullanım amacı ve yıllık toplam başvuru sayısı Milli Eğitim Bakanlığı tarafindan açıklansa da, bu başvuruların çözüm süreci, sınıflandırılmış istatistikleri gibi bilgi uçurma eyleminden sonra gerçekleştirilen iş ve işlemler hakkında bilgiler açıklanmamaktadır. $\mathrm{Bu}$ bilgilerin şeffaflık gözetilerek açıklanmasının bilgi uçurma kanallarında uygulanan işlemler hakkında net bilgiler sunarak daha kapsaml çalışmalar ortaya çıkmasına yardımcı olacağı düşünülmektedir.

\section{Kaynakça}

Adatavır (2017). Kocaali'de okul müdürü darp edildi. (Erişim: 16.11.2017), http://www.adatavir.com/kocaaliokul-muduru-darp-edildi.html

Aktan, C. C. (2015). Organizasyonlarda yanlış uygulamalara karşı bir sivil erdem, ahlaki tepki ve vicdani red davranış1: Whistleblowing. Organizasyon ve Yönetim Bilimleri Dergisi, 7(2), 19-36.
Aydın, U. (2003). İş Hukuku Açısından İşçinin Bilgi Uçurması. Anadolu Üniversitesi Sosyal Bilimler Dergisi, 2(2),79-100.

Baltacı, A. (2017a). Eğitim Örgütlerinde Bilgi Uçurma: Eğitim Çalışanlarının Bilgi Uçurdukları Kişi Ve Makamlar. Bayburt Eğitim Fakültesi Dergisi, 12(23), 57 85.

Baltacı, A. (2017b). Bilgi Uçurma: Kavram ve Kuramsal Temeller. Anemon Muş Alparslan Üniversitesi Sosyal Bilimler Dergisi, 2(5), 397-424.

Baltac1, A., \& Balc1, A. (2017). Reasons For Whistleblowing: A Qualitative Study. Eğitim Bilimleri Araştırmaları Dergisi, 7(1), 37-51.

Barnett, T., Cochran, D. S., \& Taylor, G. S. (1993). The Internal Disclosure Policies of Private-Sector Employers: an Initial Look at Their Relationship to Employee Whistleblowing. Journal of Business Ethics, 12(2), 127136.

Baxter, P., \& Jack, S. (2008). Qualitative case study methodology: Study design and implementation for novice researchers. The Qualitative Report, 13(4), 544559.

Brown, A.J. (2008). Whistleblowing in the Australian public sector: Enhancing the theory and practice of internal witness management in public sector organisations. Anu E Press: Australia.

Chiu, R. K. (2003). Ethical judgment and whistleblowing intention: Examining the moderating role of locus of control. Journal of Business Ethics, 43(1-2), 65-74.

Gall, M. D., Borg, W. R., \& Gall, J. P. (1996). Educational research an introduction.USA: Longman

Gerçek, H. (2005). Mühendisilikte Etik Sorunların Ele Verilmesi. Madencilik Dergisi, 44(4), 29-38.

KAYSİS (2017). Milli Eğitim Bakanlığı İletişim Merkezi (MEBIM) Genel Hizmet Bilgileri. (Erişim: 01.12.2017), http://www.envanter.kaysis.gov.tr

MEB (2012). Millî Ĕgitim Bakanlı̆̆l İletişim Merkezi Genelge No:2012/02. (Erişim: 02.12.2016), http://www.mevzuat.gov.tr.

Miceli, M. P., \& Near, J. P. (1984). The Relationships among Beliefs, Organizational Position, and Whistle Blowing Status: A Discriminant Analysis. Academy of Management Journal, 27(4), 687-705.

Miceli, M. P., \& Near, J. P. (1985). Characteristics of Organizational Climate and Perceived Wrongdoing Associated with Whistleblowing Decisions. Personnel Psychology, 38(3), 525-544.

Miceli, M. P., \& Near, J. P., \& Dworkin, T. M. (2009). A Word to the Wise: How Managers and Policy-Makers can Encourage Employees to Report Wrongdoing. Journal of Business Ethics 86 (3), 379-396.

Miceli, M. P., Near, J. P., \& Schwenk, C. R. (1991). Who Blows the Whistle and Why? Industrial and Labor Relations Review, 45(1), 113-130. 
Miceli, M., \& Near, J. P. (1992). Blowing the whistle: The organizational and legal implications for companies and employees. New York: Lexington

Özaslan G., \& Ünal A., (2016). Öğretmenlerde Açı̆̆a Çıkarma Davranışı: Mevcut Durum ve Öneriler. Kuram ve Uygulamada Ĕgitim Yönetimi, 22(3), 321-350.

Resmi Gazete (1961). Sayll Illköğretim ve Eğitim Kanunu. (Erişim: 02.12.2017), http://www.mevzuat.gov.tr.

Resmi Gazete (1965). 657 Sayll Devlet Memurlarl Kanunu. (Erişim: 02.12.2017), http://www.mevzuat.gov.tr.

Resmi Gazete (2014). Okul Öncesi Eğitim ve İlkögrretim Kurumlarl Yönetmeliği. (Erişim: 02.12.2017), http://www.mevzuat.gov.tr.

Resmi Gazete (2016). Kişisel Verilerin Korunması Kanunu. (Erişim: 02.12.2017), http://www.mevzuat.gov.tr.

Rothschild, J., \& Miethe, T. D. (1999). Whistle-blower Disclosures and Management Retaliation the Battle to Control Information about Organization Corruption. Work and Occupations, 26(1), 107-128.

Sağyan, S., \& Bedük, A. (2011). Örgüt Psikolojisi Yeni yaklaşımlar güncel konular. Konya: Atlas.

Toker-Gökçe, A. (2013). Teachers' Value Orientations as Determinants of Preference for External and Anonymous Whistleblowing. International Journal of Humanities and Social Science, 3(4), 163-173.

Toker-Gökçe, A. (2014a). Öğretmenlerin Farklı Bilgi Uçurma Tercihlerinde Belirleyici Olan Değer Yönelimleri. Trakya Üniversitesi Eğitim Fakültesi Dergisi, 4(2), 1-11.

Toker-Gökçe, A. (2014b). Okul yönetiminde bilgi uçurma (whistle-blowing). İçinde: İ. Aydın \& K. Yılmaz (Ed.), Prof. Dr. Haydar Taymaz Armă̆an Kitabı: Ĕ̈itim Yönetimi Denetimi ve Politikaları Yazlları (ss. 492-503). Ankara: Pegem Akademi.

Toker-Gökçe, A. (2015). Örgütlerde istenmeyen davranışlar: yıldırma (mobbing) ve bu tür davranışları önlemede yardımcı bilgi uçurma (whistle-blowing). Ankara Üniversitesi Ĕ̈itim Bilimleri Fakültesi Yayını. Ankara: Ankara Üniversitesi.

Tsahuridu, E. (2011). Whistleblowing management is risk management. İçinde: Lewis, D. \& Vandekerckhove, W. (Ed.), Whistleblowing and Democratic Values (ss. 5669). London: International Whistleblowing Research Network.

Vandekerckhove, W., Brown, A. J., \& Tsahuridu, E. (2014). Managerial responsiveness to whistleblowing: Expanding the research horizon. İçinde: Brown, AJ, Lewis, D., Moberly, R. \& Vandekerckhove, W. (Ed.), International Handbook on Whistleblowing Research (ss. 298-327). Londra: Edward Elgar.

Vandekerckhove, W. (2015). Does following a whistleblowing procedure make a difference? The evidence from the research conducted for the Francis Inquiry. İçinde: Lewis, D. \& Vandekerckhove, W. (Ed.) Developments in whistleblowing research (ss. 85-105).
London: International Whistleblowing Research Network.

Yeoh, P. (2014). Whistleblowing: motivations, corporate self-regulation, and the law. International Journal of Law and Management, 56(6), 459-474.

Yıldırım, A., \& Şimşek, H. (2008). Sosyal bilimlerde araştırma yöntemleri. Ankara: Seçkin.

Yüksel, A., Mil, B., \& Bilim, Y. (2007). Nitel araştırma: Neden, nasıl, niçin? Ankara: Detay. 